\title{
Sciendo
}

10.2478/abcsj-2021-0004

\section{Dualistic Vision in Virginia Woolf's The Waves}

\author{
LORAN GAMI \\ University of Tirana, Albania
}

\begin{abstract}
The article focuses on Virginia Woolf's novel, The Waves, a sui generis work, in which the writer explores metaphysical and epistemological issues such as the meaning of selfhood, time and identity as flux, silence and language, the self as defined by language, and other fundamental concerns. These topics are explored through a dualistic perspective. This duality permeates the entire structure of the novel through binary oppositions: the self as one/the self as plural; the lyrical/the novelistic; the mystical/the rational; narrative/formlessness; the embodied/the disembodied; potentiality/actuality; language/silence. Woolf's ambivalent approach is also at work in the way she uses language in the novel. The urge towards a teleological existence prompts her characters to turn events into a narrative that would arrange and combine them into one thread. The present article, however, shows that in The Waves the very human propensity to turn experience into a coherent story is countered by the opposite perception that this narrativizing drive is only an illusion.
\end{abstract}

Keywords: dualism, ambivalence, actuality and potentiality, language and silence, narrativize, mysticism

\section{The Background of Dualistic Thought in Virginia Woolf}

The Waves, published in 1931, is Virginia Woolf's most experimental book, one which challenged (and still does) the conventions and boundaries of the novelistic genre. Woolf's life went through several crises which were both personal and literary. The Waves was conceived in a moment of crisis in her personal, as well as literary, life in the late 1920s. After publishing To the Lighthouse, Woolf felt "more and more 
sure that [she would] never write a novel again" (Writer's Diary 122), and, in that same year, musing over the idea of writing a book which she originally called The Moths, she recorded in her diary that this book was going to be a "playpoem" (134). Ever sensitive to the critical appraisal of her work, Woolf expressed concern that she might have come "to a crisis in the matter of style" (134), and it is during this period that she started to think seriously of writing a new book which was to be something she had not ventured before. Another revealing piece of information that comes from Woolf's diary is that in this projected book she would be trying to "come to terms with [her] mystical feelings" (134). The Waves deals with such issues as selfhood and identity, time as flux, silence, the relationship between words and self, and is undoubtedly Woolf's most abstract and mystical piece of writing, "an abstract mystical eyeless book," as she defines it (Writer's Diary 134).

The Waves is permeated throughout by several binary oppositions. The first part of the present study examines the importance of dualistic thinking for Woolf, focusing on several of her fictional and non-fictional works, and briefly introduces various philosophies that might have influenced her thinking in terms of dichotomies. From the general premise of the ubiquity and importance of the dualistic perspective, my study goes on to consider these dualisms and the constant interplay of two opposing conditions or perceptions of the same phenomenon or situation. Phrases, thoughts, and moods are contradicted, contraposed, or, at least, qualified in one way or another by their opposite, thereby creating a constant rhythm. This rhythm can be felt at the 'micro' level, that is, within paragraphs, and also at the 'macro' level, in the ten shorter nature interludes interwoven with the characters' nine soliloquies. The image of the wave, with its ebb and flood phases, provides the basic rhythm which underlies the whole text and exemplifies the dualistic approach in the novel. The dualistic viewpoint is reflected in a number of binary opposites. Some of the dichotomies the article tackles are: the self as one/the self as plural; many characters/one single consciousness; the lyrical/the novelistic; the mystical/the rational; narrative/formlessness; the embodied/the disembodied, word/silence. The Waves also considers the opposition between (subjective) consciousness and the objective world 
existing independently of consciousness, which Woolf also explored in many of her previous literary and critical works. The unceasing conflict of the two opposing sides of the dualisms in The Waves is at the same time a source of tension and exhilaration.

Woolf's philosophical background was variegated and derived from her wide reading as well as her being part of a rich intellectual milieu which included family and friends - in which discussions about art, literature, philosophy, and other intellectual pursuits were always present. The purpose of the article, however, is not to elaborate on the various philosophical and intellectual influences in Woolf's literary life but rather to point out some of the ideas that might have contributed to shaping her dualistic vision. From a very early age, Woolf became acquainted with Plato's dialogues, and she even began her instruction in the Greek language in 1902, which made it possible for her to read many of Plato's Socratic dialogues in the original (Lazenby 42). One of the most important dualisms in Plato's dialogues is that between the body and the mind, a fundamental duality which has influenced the whole of Western philosophy. In all likelihood, Woolf was also acquainted with Heraclitus' (dualistic) philosophy, to which Plato refers in his works. The Heraclitean thought is evident in her essays and diary entries, as in the following example:

Now is life very solid or very shifting? I am haunted by the two contradictions. This has gone on for ever; will last for ever; goes down to the bottom of the world - this moment I stand on. Also it is transitory, flying, diaphanous. Perhaps it may be that though we change, one flying after another, so quick, so quick, yet we are somehow successive and continuous we human beings. (Writer's Diary 138)

This diary entry shows a close resemblance to Heraclitus' idea of the unity of oppositions, an idea which exerted an influence on Plato. In Symposium, the latter writes:

It is only for a while that each live thing can be described as alive and the same, as a man is said to be the same person from childhood until he is advanced in years: yet though he is called the same he does not at any time possess the same properties; he is continually becoming a new person, and there are things also which he loses [...] not only in his body but in his 
soul besides we find none of his manners or habits, his opinions, desires, pleasures, pains or fears, ever abiding the same in his particular self [...]. (207d-e)

This probing into the nature of selfhood and identity is also an important concern in The Waves. The Heraclitean thought can be felt in dichotomies such as the ego as one unified entity versus the ego as multiple selves, or the feeling that human existence is an ever-changing flux and the contrary perception that the self, for all its changes, has an immutable core.

Another important source that might have contributed to the shaping of Woolf's dualistic attitude is her knowledge and reading of philosopher G. E. Moore. ${ }^{i}$ Many of Moore's writings engage with the ancient and fundamental dualism in philosophy between materialism and idealism. Commonly categorized as a realist, he opposed both idealism and its main concept that to be is to be perceived - and materialism. The relationship between consciousness and reality was a crucial concern for Moore, as it was for Woolf. Woolf explores this duality in many of her works, and, even though she characteristically explores the inner life of the mind, her attention was no less engrossed by the (outside) reality and the possibility of that reality existing independently of our perception of it. As S.E. Rosenbaum puts it, "Moore's division between the acts and objects of consciousness" is present in Woolf's collection of short stories Monday or Tuesday, in which she "[criticises] views of reality that ignore or minimise either half of the dualism" (9). Thus, although her works are permeated throughout by the solipsistic (and idealistic) idea of mind as a prison-house from which there is no escape, an idea which entails the unknowability of the outside world, her characters still find comfort and hope in the possibility of an objective world that exists independently of them. Discussing the influence of Moore and Bertrand Russell (both philosophers were colleagues and collaborators at Cambridge) on Woolf's thought, Jaakko Hintikka asserts that the "ambivalence of Russell's ontology [...] can serve as a model of Woolf's unstated metaphysical priorities. For her, too, the emphasis on the inner world of senseexperience, feeling, and thought, is not designed to disparage the normal everyday reality but to enhance it" (12). 
The dualistic approach is also important when it comes to understanding the composition of this novel and the way Woolf conceives of the characters. While considering the path she would take to write The Waves, Woolf writes in one of her diary entries that she felt undecided between two contrary methods. She could have followed the strain she found so "spontaneous" and "natural" when writing Orlando (1928), writing "exteriorly," an experience which was a relief to her after the writing of the emotionally straining To the Lighthouse. However, Woolf feared that by doing so, she would be "ignoring the other" (Writer's Diary 136) qualities, that is, the exploration of inner being. She, therefore, decided to fuse the inner and the outer: "And what is my own position towards the inner and the outer? I think a kind of ease and dash are good; - yes: I think even externality is good; some combination of them ought to be possible" (Writer's Diary 136). In the same diary entry, she reiterates her objection against the (traditional) novelists whose novels can never grasp the moment, busy as their "business" is to "get on from lunch to dinner" (136). She writes that, like the realists, she too would like to include everything in her new book as realists do, but it had to be poeticized, it had to be "[saturated]," it "[must include nonsense, fact, sordidity: but made transparent" (137). This idea is also present in her essay "The Narrow Bridge of Art," in which Woolf states that the mind is "full of $[\ldots]$ hybrid unmanageable emotions" and that the "earth is $3,000,000,000$ years; that human life lasts but a second; that the capacity of the human mind is nevertheless boundless; that life is infinitely beautiful yet repulsive; that one's fellow creatures are adorable but disgusting" (75). It is in this atmosphere of "doubt and conflict," of "contrast and collision" (75) that the writer must find a suitable form to express all these contradictions. Similarly, in her essay "Phases of Fiction" she praises Proust's "dual vision," his method of writing, for fusing "the thinker and the poet," which contributes to creating characters and "the whole world from which [these characters] spring more like a globe, of which one side is always hidden, than a scene laid flat before us" (125-126)

Woolf makes it clear that she intends her characters in The Waves to be "almost as caricature" and that she would avoid the detailed and 
differentiated description of characters which is typical of a novel: "What I now think is that I can give in a very few strokes the essentials of a person's character" (Writer's Diary 154). The six protagonists - Bernard, Jinny, Louis, Neville, Rhoda and Susan - are indeed six individualized characters, each with their own distinctive features. Rhoda is high-strung, alienated; Neville, sensitive, anti-conformist; Jinny, the socialite; Susan, motherly and possessive; Louis, estranged and frustrated; and Bernard, the writer, the story-teller. However, the unchanging tone and style of their soliloquies, a sameness which often makes it difficult to distinguish one from another, are suggestive that the six characters might be complementary facets of the same personality. There is an interweaving of the nine sections which comprise their soliloquies, while the seventh character, Percival, even though a pivotal figure for all of them, is not ascribed one and remains absent. Constantly, images, phrases or thoughts of one character are reprised by the others, thereby interlinking the six of them. The soliloquies merge into one another and the result seems to be a sort of collective self, a supra-self, which transcends and blurs each individual ego and unifies them all. Through the interlocking of images which connect the six protagonists, "a picture is created that portrays these six figures not as a social group but as a single organism — one symbol of a common humanity" (Freedman 252).

The form that Woolf chose to describe their consciousness is unique and different from other modernist works, even her own, one which she would not repeat in her subsequent novels. The characters are trapped in their own ego (after all, the whole novel is composed of soliloquies, not dialogues), yet, at the same, time they seem to communicate with one another. Even though not in a dialogic form, yet there is a constant communication and communion between them. James Naremore remarks that "the voices we hear are detached from their actual counterparts and do not represent consciousness except indirectly. [...] These voices seem to inhabit a kind of spirit realm. [...] [T] hey imply knowledge of a life without personality" (173). Woolf distinguishes herself by dismissing the restrictiveness of other modernist writers who "relied entirely on depicting the egos of the characters" (Naremore 175). This is the reason why the novel does not portray "simply the consciousness of Bernard, Susan, 
Jinny, Neville, Rhoda, or Louis, but their being; not their existence but their essence" (Naremore 175). The unresolved duality emerges from the constant exploration of the psychology of the characters and the metaphysical rendering of the meaning of self, life, and time.

\section{The Most Important Dualities in The Waves}

The dualistic perspective is visible in the opposition between two contradictory views of self: on the one hand, the self as a whole, undivided entity, and, on the other, the self as splintered and disintegrated. In "Reflections in a Motor Car," while journeying in a motor car and contemplating the landscape, the speaker's self (possibly Woolf herself) is split into several selves. These various selves vie for attention and record various aspects of the landscape the speaker's eye imbibes. In the end, she feels the need to summon them together: "Now we have got to collect ourselves; we have got to be one self" (10). The last, long fragment (Bernard's soliloquy) in The Waves has the function of recapitulating the nine fragments and the life story of the six characters. In a similar way tothe speaker in "Reflections in a Motor Car," the characters in The Waves are intensely aware of the fundamental opposition between the self as integrated and undivided and the self as multiple and disintegrated. This echoes Heraclitus, Plato, and the long-standing philosophical debates on the (in)stability of the ego. Bernard, the story-teller, is better equipped than the other five characters to voice this duality and proclaims that he is "not one and simple, but complex and many" and that he is "more selves than Neville thinks" (385-386).

Woolf was deeply preoccupied to capture that part of being which constitutes the 'real' or the 'authentic.' This authentic self, however, is ever elusive and contingent; it is a self shaped and influenced by the Other. The speaker in "Street Haunting," for instance, has an evening walk and feels that she "shed[s] the self our friends know us by" and that she is happy to be "part of that vast republican army of anonymous trampers, whose society is so agreeable after the solitude of one's own room" (20). The same idea is stated, albeit in a regretful tone, when Neville muses upon seeing Bernard approaching him: "how painful to be 
recalled, to be mitigated, to have one's self adulterated, mixed up, become part of another. As he approaches I become not myself but Neville mixed with somebody-with whom? [...] [I]t is to Bernard that I shall put the question, Who am I?" (382). Such an attempt at delineating the "unadulterated" self pervades the book from beginning to end. In quest of an answer to the fundamental question "Who am I?", Woolf's characters seem to distrust and resent any influence, which they fear would distance them from real selfhood. Throughout her life, Woolf was haunted by the question of what the meaning of the self is, a concern echoed in Bernard's words: "I [...] cannot be entirely sure what is my self. The authentics, like Louis, like Rhoda, exist most completely in solitude" (402). Thus, Woolf might be suggesting that, in order to get at the authentic self, one requires isolation, a view which leads to solipsism.

However, the antinomian perspective in Woolf allows, even necessitates, the opposite view. Woolf was particularly interested in the "question of whether we are merely isolated individuals or constituent parts of a much greater whole" (Bradshaw xiv). In "Street Haunting," the speaker feels elated and relieved upon leaving her house and "shedding" her self (or, at least, one of her selves). She feels that the "shell-like covering which our souls have excreted to house themselves, to make a shape distinct from others, is broken" (22). What is left after the breaking of the shell is "an oyster of perceptiveness, an enormous eye" (22). She is able to take in the beauty of everything she sees while going through the winter streets. "Leaving the straight lines of personality" and "putting on briefly $[\ldots]$ the bodies and minds of others" is, the speaker asserts, "one of the greatest pleasures" (35). Naremore remarks that with Woolf "the ego or the self is born out of an act of assertion," and that "it is [...] unthinkable to be 'carried on passively' if one wishes to retain that active contact with the everyday world of relationships with [what] we normally call living" (176). However, the dualistic perspective being ubiquitous in Woolf, the characters often find the flight from the ego and its connectedness with the world as a welcome relief. This voiding of the self is present not only in The Waves but also in her other short stories and novels, such as Mrs Dalloway or To the Lighthouse. 
The interconnectedness of the six characters and the merging of their selves are not only a cause of anxiety and distress, but also one of exhilaration. This sense of exhilaration is experienced whenever the self is described as forever becoming and changing shape when "illuminated" by the other. There is energy and potentiality in this unstable and centerless concept of a self that is forever changing under the influence of other personalities: "I feel [...] the delicious jostle of confusion, of uncertainty, of possibility, of speculation. ... I, mixed with an unknown Italian waiter. [...] There is no stability in this world. [...] We are for ever mixing ourselves with unknown quantities" (402). A further example from one of Bernard's soliloquies illustrates this idea: "when [...] I try to break off [...] what I call 'my life,' it is not one life that I look back upon; I am not one person; I am many people; I do not altogether know who I am-Jinny, Susan, Neville, Rhoda, or Louis" (496). The self is thus not a stable, but rather a protean entity that accrues and mutates whenever it comes into contact with other beings. This duality between a stable self and a mutable and impressionable self constitutes one of the oppositions at the core of The Waves.

The tension between the characters' perception of their own selves and how they think the others perceive them is one of the many oppositions in this novel. This is a consideration that vexed virtually all modernist writers. Ruth Miller remarks that in The Waves, "whenever a person is seen by someone else, he becomes aware of the restrictions imposed by the other's preconceptions" (23). This sensitivity undermines the exaltation of having one's self merged with that of others. There is an ongoing struggle between the self's reluctance to be subjected to a definition and delineation and the natural tendency of the Other to pinpoint, to define a stable self. The six protagonists in The Waves struggle to free themselves from all tyrannical definitions of the self, which might indicate their desire for freedom and authenticity. There are a number of passages in which they feel limitless and undefinable: "I am merely 'Neville' to you, who see the narrow limits of my life [...] But to myself I am immeasurable; a net whose fibres pass imperceptibly beneath the world. My net is almost indistinguishable from that which it surrounds" (461). There is a sense of limitless potentiality that characters 
in The Waves feel when contemplating their own selves. It is an ego which knows no bounds and includes immensities. This Romantic perception of Woolf's characters is, however, undercut by their painful and constant self-consciousness.

Neville's "immeasurable" self refers to yet another important duality, that between potentiality and actuality, a duality that Woolf might have encountered in Aristotle. The self is always caught between these two opposite poles in The Waves. The vast potential paths that people see before themselves are a source of energy and vitality. This is what prompts Bernard to say:

The crystal, the globe of life as one calls it, far from being hard and cold to the touch, has walls of thinnest air [...] Whatever sentence I extract whole and entire from this cauldron is only a string of six little fish that let themselves be caught while a million others leap and sizzle, making the cauldron bubble like boiling silver, and slip through my fingers. (485)

The protagonists in The Waves have a tendency to postpone taking a definite course, which would inevitably annul all other potential pathways. The self is forever a becoming, eluding a definite condition. This clinging to potentiality and fending off any actual course is what gives Woolf's characters and their lives a sense of irreality and creates an unstable and fleeting image of selfhood.

However, as with all dualisms, potentiality is counterbalanced by the sense of actuality, of concreteness, by the feeling that the self exists as a specific entity, actuated by the two fundamental metaphysical concepts, space and time. Actuality seems to annul the flickering paths that are open by potentiality. This sense of concreteness and actuality, however, has the welcome effect of saving and safeguarding them from irreality and chaos. Yet, the action of choosing in life is often met with regret: "Change is no longer possible. We are committed. Before [...] all simmered and shook; we could have been anything. We have chosen now, or sometimes it seems the choice was made for us" (461). The novel follows the life story of the six characters, and, towards the end, the elderly Bernard, who is trying to sum their lives up, casts his forlorn and regretful eye on all those potential selves he might have been if he had chosen other paths: 
Thus when I come to shape $[\ldots]$ the story of my life $[\ldots]$ I have to recall things gone far, gone deep, sunk into this life or that $[\ldots]$ dreams $[\ldots]$ and the inmates, those old half-articulate ghosts who keep up their hauntings by day and night $[\ldots]$ who put out their phantom fingers and clutch at me as I try to escape - shadows of people one might have been; unborn selves. (504)

These potential selves, the "shadows of people" one might have been, acquire a reality and life of their own. In The Waves, these unborn selves seem to be as real - if not more - as that self actuated through the path the character chose (or, as they often feel, was chosen for them). The ghosts of those unborn selves are always with(in) the present self, and it is the actuated (or real) self that becomes shadowy and unreal.

\section{Dualistic Perspective and Language}

The philosophical issues explored in The Waves are inextricably linked with the status Woolf accords language. This final part explores the dualistic relationship between language and silence, as well as the mysticism in the novel. Among the six characters, Bernard, the writer, and Neville, the poet, or rather a poet manqué, are especially concerned with language. From the very first soliloquy, when still at nursery, Bernard seems intensely aware of the six characters' identity and communion through words: "But when we sit together [...] we melt into each other with phrases" (342). Even alienation is described as estrangement from words by Rhoda: "I shall be a clinger to the outsides of words all my life" (361). Neville, too, is distrustful of language, and instinctively feels that its discriminative and pigeonholing nature distances him from the essence and beauty of things: "In a world which contains the present moment [...] why discriminate? Nothing should be named lest by so doing we change it. Let it exist, this bank, this beauty, and I, for one instant, steeped in pleasure" (381). Such passages suggest that Woolf considered language an obtuse and inadequate system, unable to grasp the fleetingness and various shades of the present moment. This skepticism and even resentment towards words is also expressed in a number of her diary entries, in one of which she writes: "I detest my own volubility. Why be always spouting words?" (Writer's Diary 126-127). As Naremore puts it, 
although Woolf "is a great verbal craftswoman," there is nevertheless "a vagueness about much of her language, reflecting her basic misgivings about the ego and about the words which are its signs" (188-189). That might be one of the reasons why she is reluctant to be identified with the stream-of-consciousness technique, which, in her view, signified an individual confined in the prison of the ego. Her style differs considerably from that of other modernists such as James Joyce, Dorothy Richardson, or William Faulkner. Since the ego is created by words and can only be reached through words, unlike Joyce, Woolf remains skeptical of language.

Yet Woolf's approach to language in The Waves follows the dualistic perspective. Throughout the book - except for the last fragment, Bernard asserts that reality can only be apprehended through words. For him, words not only make sense of reality, but they create it: "Let me then create you" (383), Bernard says, and Neville, critical of this tendency, complains that Bernard identifies reality with words: "[L]et Bernard begin. [...] Let him describe what we have all seen so that it becomes a sequence. Bernard says there is always a story. I am a story. Louis is a story" (355). Bernard always feels the urge to narrativize, to turn every event into language and a (hi)story. It is a tendency which serves to fight off the 'enemy' - incoherence, chaos and nothingness: "I must open the little trap-door and let out these linked phrases in which I run together whatever happens, so that instead of incoherence there is perceived a wandering thread, lightly joining one thing to another" (362). For him, storytelling is a means of imposing order upon a chaotic world. The six characters often experience the void and nothingness and cannot bear the meaninglessness of existence. They need to feel that life has a purpose and that they are not merely specks of dust blown hither and thither by random and design-less events: "Tuesday follows Monday; Wednesday Tuesday. So the being grows rings; identity becomes robust. What was fiery and furtive like a fling of grain cast into the air and blown hither and thither by wild gusts of life from every quarter is now methodical and orderly and flung with a purpose" (488).

However, the novel follows the wave-like rhythm of advancement and retraction so that the all too human urge to turn experience into a 
coherent story is countered by the opposite perception that this narrativizing drive is only an illusion. Even Bernard, the most word-prone among the characters, recognizes the conventionality and arbitrariness of imposing an ordering narrative over life since reality is much more variegated, incoherent, and decentered: "I have made up thousands of stories; I have filled innumerable notebooks with phrases to be used when I have found the true story, the one story to which all these phrases refer" (445). But he himself admits that he has never found that story and asks: "Are there stories? [...] But why impose my arbitrary design? Why stress this and shape that and twist up little figures like the toys men sell in trays in the street? Why select this, out of all that - one detail?" (445). The question might have been posed - metafictionally - by Woolf herself and echoes her desire to "put everything in" and "eliminate all waste" (Writer's Diary 136). Thus, Bernard, too, recognizes that narrativizing implies imposing an arbitrary design onto an otherwise design-less and incoherent reality. Story-telling might be construed as distancing oneself from truth and authentic life:

in order to $[\ldots]$ give you my life, I must tell you a story - and there are so many, and so many - stories of childhood, stories of school, love, marriage, death, and so on; and none of them are true. Yet like children we tell each other stories. [...] How tired I am of stories, how tired I am of phrases that come down beautifully with all their feet on the ground! (475)

There are striking similarities between Bernard's and Woolf's plights. Woolf, too, felt skeptical that language represents a tool or system for making sense of reality and even shaping it, and she longed to record "unmediated" reality (Warner 103).Yet, she is well aware that the result would be a formless, incoherent flux, and that, ultimately, it is art that resists such a flux. John Mepham argues that "[t]hrough Bernard [Woolf] can speak to us" and "we can see" that Bernard, the writer in the novel, is "one of Virginia Woolf's most self-conscious self-portraits" (141). Bernard can be viewed as Woolf's voice in The Waves, and the novel ends with his recapitulation of his own life, his friends' lives, and of the whole story. Taking, however, into account the book's deeply ambivalent mood, the whole idea of 'summing up' might be ironic since the more Bernard tries to sum up, the more his narrative dissolves until in the end he feels 
words are not enough. Thus, Bernard may not be Woolf's mouthpiece but rather, as Jane Marcus puts it, "a parody of authorship" (61).

Towards the end of his final soliloquy Bernard experiences the annihilation of the self, which he sees as a sort of death: "For one day as I leant over a gate [...] the rhythm stopped. [...] I saw through the thick leaves of habit. [...] I regretted so much litter, so much unaccomplishment and separation" (500). After this epiphanic moment, which he refers to as "the eclipse" of the sun (501), Bernard sees everything differently: "From me had dropped the old cloak, the old response; the hollowed hand that beats back sounds. Thin as a ghost, leaving no trace where I trod [...] I walked alone in a new world, never trodden" (502). He feels words cannot "shelter" him, there are no words to describe this experience, a world without ego (the ego is metaphorically described as "the sun"). Once habit breaks down, he realizes that language too has been just a means of giving shape and coherence to a life which is essentially meaningless and chaotic. "How describe or say anything in articulate words again?" (503), he wonders. He who has always given meaning to life through words and story-telling is now left without this omnipresent and never-failing prop and feels that the truth which language purports to convey has been an illusion. This is a concern that Woolf dwelt upon in many of her fictional and non-fictional works. ${ }^{\text {ii }}$

Once the "rhythm" stops, Bernard feels that he is able to get at the truth behind it all and sees life as merely habit and litter that has encumbered and prevented him from apprehending the truth. He tries to address his self but "[this] self now [...] made no answer. He threw up no opposition. He attempted no phrase. [...] I listened. Nothing came, nothing, I cried then with a sudden conviction of complete desertion, Now there is nothing" (Waves 501). The death of the self, however, comes as an epiphany. Bernard realizes that behind the self there is nothing(ness). Towards the end of the novel, when the characters have grown older, they seem "more ready to give themselves up to the void outside themselves" (Naremore 185). This understanding of the nothingness and meaninglessness of a non-existent self shatters Bernard's greatest illusion. He sees human beings as voided of all meaning, and this has destroyed the comforting illusion and foundation of a solid self. This surely is a sort of 
death: "A man without a self, I said. A heavy body leaning on a gate. A dead man. How can I proceed now, I said, without a self, weightless and visionless, through a world weightless, without illusion?" (502). When the veil is torn, revealing the void behind it, the conventional idea that language is an adequate and natural system that captures and gives meaning to selfhood is shown as delusive. The articulated words, the words that "fall with all their feet on the ground," (507) do not work. Bernard feels the need to find a new language and discards the notebook he has kept throughout his life with the aim of recording reality:

My book, stuffed with phrases, has dropped to the floor. [...] I need a little language such as lovers use, words of one syllable such as children speak. [...] I need a howl; a cry. When the storm crosses the marsh and sweeps over me where I lie in the ditch unregarded I need no words. Nothing neat. Nothing that comes down with all its feet on the floor. [...] I have done with phrases. (507)

When the self is stripped of illusion and the belief in language as a solid refuge collapses, silence seems to be the inevitable result: "How much better is silence. [...] Let me sit here for ever with bare things, this coffee-cup, this knife, this fork, things in themselves, myself being myself' (507). In these moments of solitude and silence, Bernard seems to have finally managed to immobilize the flux. The self is detached from the material and earthly, and his identity/ego is almost wholly dissolved: "As silence falls I am dissolved utterly and become featureless and scarcely to be distinguished from another. It does not matter. [...] I reflect now that the earth is only a pebble flicked off accidentally from the face of the sun and that there is no life anywhere in the abysses of space" (467).

This experiencing of solitude and silence is a mystical moment of peacefulness and completeness. Bernard, who has always made sense of life through words and has created the self and the others through language, now longs for silence. It is the only moment when, to borrow Joyce's words, the "whatness" of things seems to "[leap] [...] from the vestment of its appearance" (213) and becomes visible to him - probably to Woolf as well. For the first time, things are seen in themselves - also a suggestion of the Kantian 'thing-in-itself' - divested of illusion and the veil of words, which arbitrarily impose a meaning and design on them. 
This is a mystical moment of the total annihilation of the self, when it has lost all materiality, has become disembodied, a condition which would lead to the obliteration of all dualities. This total extinction of self is also found in To the Lighthouse, in which Mrs. Ramsay feels the need to "[lose] personality" (225). She, too, longs for silence and solitude: "She could be herself, by herself. And that was what now she often felt the need of - to think; well not even to think. To be silent; to be alone. All the being and the doing, expansive, glittering, vocal, evaporated; and one shrunk [...] to being oneself, a wedgeshaped core of darkness [...]" (225). This escape and release of the self from all material attachment gives Mrs. Ramsay the freedom she yearns for. Only when the ego is effaced does she feel free, and, paradoxically, it is at these moments that she feels most herself and comes closest to being face to face with her real, authentic self - if such a thing exists. This is a paradoxical dualism which Woolf never meant to resolve in her writings as she considered it a fundamental condition of human existence. The "shrinking" is paradoxically a condensation and gaining: "This core of darkness could go anywhere [...] Not as oneself did one find rest ever, in her experience [...] but as a wedge of darkness" (To the Lighthouse 225). The arduous endeavor to come to terms with one's self and to pare down the inessential and superfluous layers of one's own existence leads to a condensation of being. However, "this wedge of darkness" which gives freedom, peace and stability to being is insubstantial, ineffable, and the whole experience approaches the mystical or quasi-mystical.

Arguably, Bernard's final soliloquy somehow resolves the dualisms and contradictions that abound in The Waves. Bernard feels his being "[i]mmeasurably receptive, holding everything, trembling with fullness" (505) now that, after the death of the self, he is immune to desire and curiosity. Does Woolf resolve these contradictions by proposing, through Bernard, passive resignation and a mystical surrendering of the self? Drawing this conclusion to this - to use Woolf's words - "unintelligible book" (Writer's Diary 171) is certainly tempting, and the last fragment might perfectly illustrate it. However, in the very last two paragraphs of Bernard's long soliloquy, there is a volte-face, with the elderly Bernard seeing the approaching dawn and feeling "once more [...] a new desire" 
arising in him and summoning up his courage to launch an attack against "the enemy," death, "unvanquished and unyielding" (508). The entire soliloquy, which oscillates dualistically between the passive surrender and spirited defiance, might be read as representing the "crucial experience" of "loss and recovery of self" (Rosenbaum 33) and the reassertion of consciousness in order to fight off its enemy - "insensitive matter" (Rosenbaum 35). Woolf's novel remains highly ambivalent, and the last sentences contradict the mystical proposal of the surrendering of the self, which would inevitably lead to the collapse of all dualities. There is, however, no conclusive resolution, since after this last paragraph, comes the final one-sentence nature interlude: "The waves broke on the shore" (508). This interlude occurs at nightfall, which serves to undermine Bernard's enthusiastic apostrophe, by emphasizing man's helplessness vis-à-vis the impersonal forces, whether nature or death.

Thus, the dualistic nature of The Waves and the resulting tension and indeterminacy remain unresolved until the end. With The Waves, Woolf sought to "put everything in" (Writer's Diary 136), and neither of the two poles of the dualism is given precedence. It might be argued that rather than dialectically fusing the opposite sides into a synthesis, Woolf has allowed them to exist side by side and not be mutually exclusive. In keeping with its dualistic character, the novel can be read both as a highly formal composition with stylized contrapuntal and interconnected images highlighting beauty and formal arrangement, and also a work in which Woolf addresses and explores the most essential existential questions. Woolf's highest artistic achievement in The Waves is precisely her attempt to let the two coexist in a single literary work, which remains unique to this day.

\section{Notes:}

${ }^{i}$ Leonard Woolf and other members of the Bloomsbury - the intellectual circle Woolf was part of - had known Moore. Leonard Woolf had been part of the Cambridge discussion group called the Apostles, that Moore had also been a member of in his student years.

${ }^{i i}$ In the third part of To the Lighthouse, for example, Lily Briscoe, the artist, feels that she "wanted to say not one thing, but everything," but concludes that it is impossible to say anything to anybody because "The urgency of the moment 
always missed its mark. Words fluttered sideways and struck the object inches too low" (311).

\section{Works Cited}

Bradshaw, David. Introduction. The Waves. Cambridge: Cambridge UP, 1987. xixxix.

Freedman, Ralph. The Lyrical Novel. Studies in Herman Hesse, Andre Gide, and Virginia Woolf. Princeton: Princeton UP, 1963.

Hintikka, Jaakko. "Virginia Woolf and Our Knowledge of the External World." The Journal of Aesthetics and Art Criticism 38.1 (1979): 5-14.

Joyce, James. Stephen Hero. New York: New Directions, 1963.

Lazenby, Donna J. A Mystical Philosophy: Transcendence and Immanence in the Works of Virginia Woolf and Iris Murdoch. London: Bloomsbury, 2014.

Marcus, Jane. Hearts of Darkness: White Women Write Race. New Brunswick, NJ: Rutgers UP, 2004.

Mepham, John. Virginia Woolf: A Literary Life. Hampshire: Macmillan, 1991.

Miller, C. Ruth. Virginia Woolf: The Frames of Art and Life. Hampshire: Macmillan, 1988.

Naremore, James. The World Without a Self: Virginia Woolf and the Novel. New Haven: Yale UP, 1973.

Plato. Plato in Twelve Volumes. Vol. 9. Trans. Harold N. Fowler. Cambridge, MA: Harvard UP, 1925.

Rosenbaum, S. P. Aspects of Bloomsbury: Studies in Modern English Literary and Intellectual History. Hampshire: Macmillan, 1998.

Warner, Eric. Virginia Woolf: The Waves. Cambridge: Cambridge UP, 1987.

Woolf, Virginia. A Writer's Diary. Ed. Leonard Woolf. New York: Harcourt, 1954.

---. "Phases of Fiction." Granite and Rainbow. Ed. Leonard Woolf. New York: Harcourt, 1958. 93-145.

---. "Reflections in a Motor Car." Death of the Moth and Other Essays. San Diego: Harcourt, 1974. 7-11.

---. "Street Haunting." Death of the Moth and Other Essays. San Diego: Harcourt, 1974. 20-36.

---. "The Narrow Bridge of Art." Selected Essays. Ed. David Bradshaw. Oxford: Oxford UP, 2008. 74-84.

---. The Waves. Collected Novels of Virginia Woolf. Ed. Stella McNichol. Hampshire: Macmillan, 1992.

---. To the Lighthouse. Collected Novels of Virginia Woolf. Ed. Stella McNichol. Hampshire: Macmillan, 1992. 